\title{
OAK RIDGE OPERATIONS \\ NUCLEAR MATERIALS MANAGEMENT PROGRAM \\ HANDBOOK
}

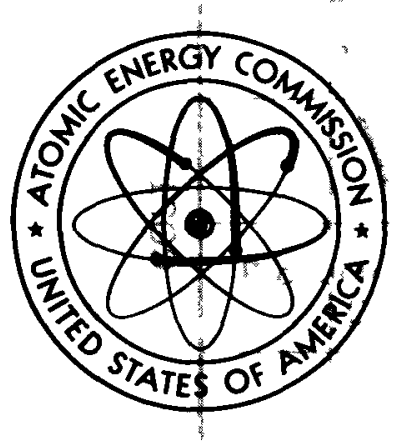

United States Atomic Energy Commission

Oak Ridge Operations Office Oak Ridge, Tennessee 


\section{DISCLAIMER}

This report was prepared as an account of work sponsored by an agency of the United States Government. Neither the United States Government nor any agency Thereof, nor any of their employees, makes any warranty, express or implied, or assumes any legal liability or responsibility for the accuracy, completeness, or usefulness of any information, apparatus, product, or process disclosed, or represents that its use would not infringe privately owned rights. Reference herein to any specific commercial product, process, or service by trade name, trademark, manufacturer, or otherwise does not necessarily constitute or imply its endorsement, recommendation, or favoring by the United States Government or any agency thereof. The views and opinions of authors expressed herein do not necessarily state or reflect those of the United States Government or any agency thereof. 


\section{DISCLAIMER}

Portions of this document may be illegible in electronic image products. Images are produced from the best available original document. 


\section{OAK RIDGE OPERATIONS \\ NUCLEAR MATERIALS MANAGEMENT PROGRAM \\ HANDBOOK}

\section{DISCLAIMER}

This report was prepared as an account of work sponsored by an agency of the United States Government. Neither the United States Government nor any agency thereof, nor any of their employees, makes any warranty, express or implied, or assumes any legal liability or responsibility for the accuracy, completeness, or usefulness of any information, apparatus, product, or process disclosed, or represents that its use would not infringe privately owned rights. Reference herein to any specific commercial product, process, or service by trade name, trademark, manufacturer, or otherwise does not necessarily constitute or imply its endorsement, recommendation, or favoring by the United States Government or any agency thereof. The views and opinions of authors expressed herein do not necessarily state or reflect those of the United States Government or any agency thereof.

August 1974

United States Atomic Energy Commission
0ak Ridge Operations Office
Oak Ridge, Tennessee 
This handbook has been prepared to acquaint the staffs of the 0ak Ridge Operations Office and its contractors with current policies, responsibilities, and procedural matters associated with nuclear materials management. Inasmuch as portions of the AEC's nuclear materials management program are still in an evolutionary phase, this handbook must be considered as a guide.

Nuclear materials management must be viewed as an essential part of program planning and execution where nuclear materials are involved.

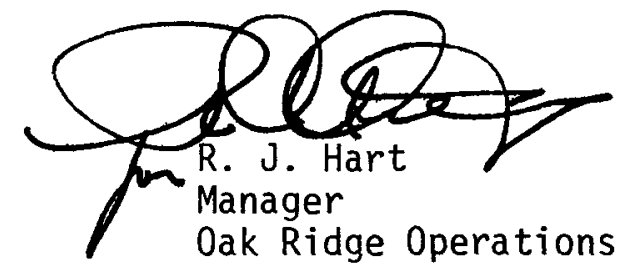




\section{CONTENTS}

\section{$\underline{\text { Page }}$}

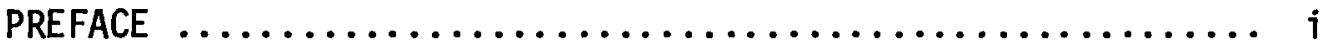

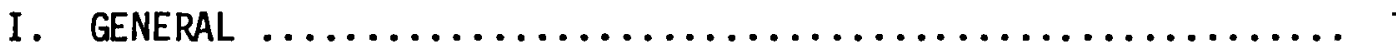

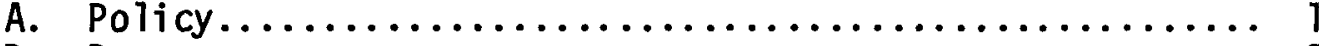

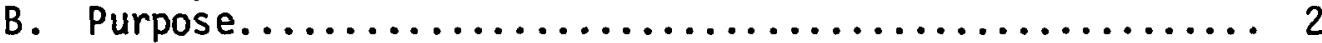

II RESPONSIBILITIES $\ldots \ldots \ldots \ldots \ldots \ldots \ldots \ldots \ldots \ldots \ldots \ldots \ldots \ldots$

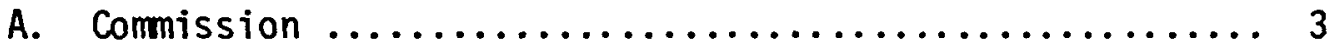

B. Director, Division of Production \& Materials Management. 3

C. Director, Office of Planning and Analysis........... 5

D. Assistant General Manager, Controller.............. 5

E. Director, Division of Safeguards and Security.......... 5

F. Directors, Headquarters' Program Divisions........... 6

G. Managers of Field Offices................... 7

H. Director, OR Materials Management Division........... 9

I. Directors of OR Manufacturing, Research and Technical Support, and Uranium Enrichment Operations Divisions.... 10

J. OR Operating Contractors..................... 11

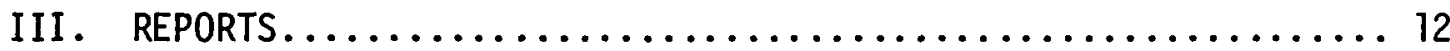

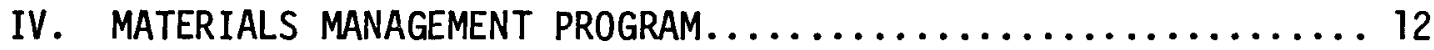

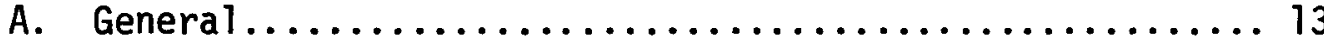

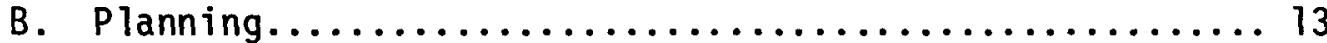

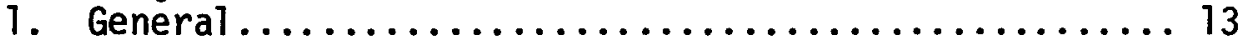

2. Forecasts.............................. 14

3. Materials Management Plans................ 15

4. Inventory Management.................... 19

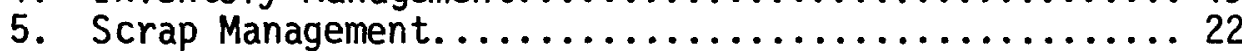

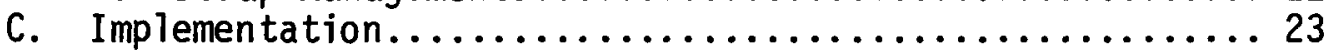

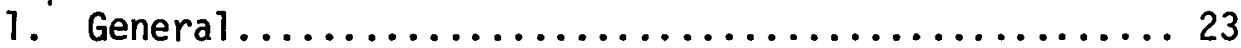

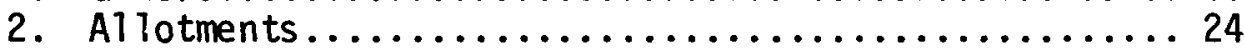

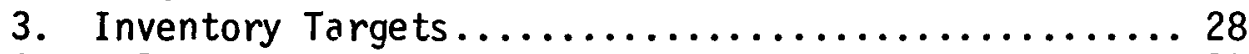

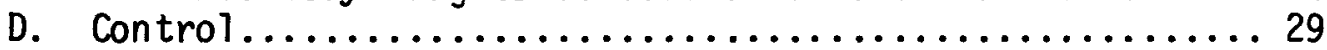

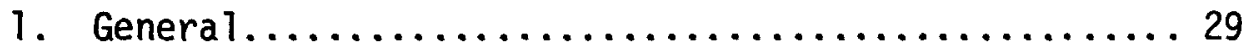

2. Contractor Materials Management Appraisal Activities 29

3. Assessment of Contractor Inventories of Nuclear Materials............................... 31 
A. SPECIFIC PROCEDURES FOR PREPARING NUCLEAR MATERIALS

FORECASTS ................................ 32

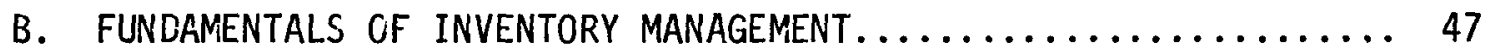

C. NUCLEAR MATERIAL ALLOTMENTS AND INVENTORY TARGETS .......... 55

D. MATERIALS MANAGEMENT APPRAISAL ACTIVITIES ............. 63

E. ASSESSMENT OF CONTRACTOR INVENTORIES OF NUCLEAR MATERIALS .... 66

F. ANALYTICAL STUDIES ......................... 69

G. EXCESS MATERIALS ......................... 73 
OAK RIDGE OPERATIONS

NUCLEAR MATERIALS MANAGEMENT PROGRAM HANDBOOK

\section{GENERAL}

\section{A. Policy}

1. In his September 16, 1971, memorandum to the Division Directors and Assistant General Managers, the General Manager endorsed the following objectives of nuclear materials management:

"a. To supply materials to program divisions, to contractors, to other Government agencies, and to foreign nations at the lowest cost to the Government, insofar as practicable, through optimizing the choice between supplying those needs from existing inventories, new production, or by purchase.

"b. To strengthen the management of existing inventories by providing more specific guidance and standards and by optimizing inventory levels, including levels of in-process inventories, and decisions with respect to retention or disposal of inventories that cannot be justified."

2. Effective nuclear materials management requires recognition that nuclear materials, like funds, are economic resources 
with competitive requirements. Optimization of nuclear materials utilization requires decision rules which recognize the value of nuclear materials, in a total cost concept, for evaluation of alternates in meeting program needs. Such policies and decision rules should assure proper integration of nuclear materials management procedures with program planning, production cost determinations, nuclear materials safeguards, and other AEC and contractor functions including nuclear safety and quality assurance. Accordingly, no program planning can be considered complete until the nuclear materials management aspects of the program in question have been recognized and properly evaluated. The cost and values of nuclear materials involved must be considered before initiating new programs or continuing existing programs which use nuclear materials. Program benefits should clearly equal or exceed a suitable use charge (presently 10\% per annum) or the value of the materials consumed, whichever is greater, before the required nuclear material is made available to support the program.

B. Purpose

1. The purpose of this handbook is to provide guidance for 
management of nuclear materials under the jurisdiction of the Oak Ridge Operations Office.

2. The provisions of this handbook and amplifying instructions by the OR Materials Management Division apply to all OR license-exempt contractors who possess nuclear materials and to licensed contractors processing Government-furnished material.

3. The materials covered by this handbook are U-233, uranium (depleted, normal, and enriched in U-235), plutonium, Pu-238, tritium, deuterium, and boron-10. The Director, Materials Management Division, will advise of specific materials which may be identified for special reporting and new materials which may be added.

\section{RESPONSIBILITIES}

A. The Commission approves the annual AEC Materials Management Plan (MMP) for the production, procurement, and utilization of nuclear materials.

B. The Director, Division of Production and Materials Management (AEC Materials Manager):

1. Develops policies, procedures, and standards for the management of nuclear materials.

2. Prepares the annual AEC-wide MMP and the Materials Management Supplement to the budget for submission to the 
Budget Review Committee, as provided by AECM 1301, the General Manager, and the Commission.

3. Conducts periodic reviews and evaluations of field office materials management programs and activities.

4. Reviews, consolidates, and approves forecasts of nuclear material requirements (in collaboration with HQ program divisions) for AEC civilian and military programs (materials production, weapons production, reactors, and research and development programs).

5. Identifies and maintains managerial control of nuclear materials in excess of the quantities required for the currently approved operating programs of the program divisions.

6. Reviews schedules for the processing of nuclear material scrap and irradiated fuel necessary to meet program requirements on an economic and timely basis.

7. Reviews and analyzes the nuclear material resources required and assures that such materials reflect soundly developed and fully justified programs and are consistent with budgets.

8. Conducts AEC-wide planning and analysis related to production planning and utilization of nuclear materials. 
9. Administers the AEC-wide nuclear materials allotment system.

10. Recommends purchase of nuclear material required for AEC programs.

C. The Director, Office of Planning and Analysis:

1. Develops the forecasts of special nuclear material required from the $A E C$ for domestic and foreign nuclear power reactors.

2. Provides analysis of the AEC MMP for consistency to overall AEC program planning and objectives.

D. The Assistant General Manager, Controller:

1. Provides standard costs for nuclear materials and, as necessary, related cost formulas.

2. Provides discount rates.

a. Participates with Division of Production and Materials Management in establishment of nuclear materials values.

4. Provides advice on financial matters relating to the materials management program.

E. The Director, Division of Safeguards and Security: Provides nuclear material inventory and transaction reports from the Nuclear Materials Information System. 
F. The Directors, Headquarters' Program Divisions:

1. Analyze nuclear material inventories for their programs periodically to assure that such inventories are justified and that materials utilization is optimized.

2. Budget sufficient funds for preprocessing and transportation of scrap and irradiated fuels to assure that such materials are handled in accordance with established materials management practices.

3. Assure that both cost-type and fixed-price contracts issued for their programs contain adequate materials management provisions.

4. Provide realistic forecasts of nuclear material requirements for programs for which they have a responsibility.

5. Assure that forecasts of nuclear material requirements are compatible with budgets and other planning documents such as Five-Year Spring and Fall Projections.

6. Implement a materials management program for all activities under their jurisdiction in conformity with the policies, procedures, and standards set forth in the AECM and as otherwise instructed. 
G. The Managers of Field Offices:

1. Implement materials management programs for all activities under their jurisdiction in conformity with the policies, procedures, and standards set forth in applicable AECM chapters and appendices, and as otherwise instructed.

2. Assure that inventories held by contractors for their programs are justified and that materials utilization is optimized.

3. Assure that both cost-type and fixed-price contracts issued for their programs contain adequate materials management provisions.

4. Provide HQ with realistic forecasts of nuclear material requirements for programs for which they have responsibility.

5. Develop and implement a formal program for the management of nuclear materials at contractor operations for which the field office is responsible.

6. Develop and provide to HQ an annual materials management plan for programs for which the field office is responsible. 
7. Perform periodic reviews of materials management activities at contractor operations for which the field office is responsible.

8. Maintain an allotment control system to assure that nuclear materials allotted for their programs are not exceeded.

9. Perform specific analytical studies related to materials management as required to assure optimum material planning and utilization and as may be directed by HQ program divisions and/or the AEC Materials Manager.

10. Assure that scrap and other excess materials are identified properly and handled promptly in accordance with current AEC policy.

11. Assure that scrap is reported promptly to the appropriate central scrap management office (CSMO) and funds are available to preprocess, package, and ship the scrap as directed by the CSMO.

12. Assure that nuclear materials are acquired for their programs only to the extent that they are required to meet program objectives.

13. Assure that contractors for which they have responsibility perform required preprocessing of irradiated fuels consistent with current AEC policy on disposition of such fuel. 
14. Assure that contractors for which the field office has administrative responsibility correctly identify and accurately report nuclear materials quantity data.

H. The Manager, Oak Ridge Operations, has, through the Assistant Manager for Operations, designated the Director of the Materials Management Division (MMD) as the OR Nuclear Materials Manager. In this capacity the MMD Director will:

1. Through reviews and evaluations, assure that nuclear materials management policies and procedures set forth in AECM 7451 and HQ directives are accomplished for all programs under the jurisdiction of $O R$.

2. Formulate policies, procedures, and plans to achieve effective nuclear materials management within $O R$.

3. Prepare annually, with assistance as needed from OR contract administrators, 12-year plans which provide for the timely and economical use of nuclear materials consistent with program assumptions.

4. Review activities of OR program divisions and appraise contractors to assure compliance with approved materials management plans, policies, and procedures, and make findings and recommendations on such reviews 
and appraisals available to OR contract administrators and contractors for comment and corrective action as appropriate.

5. Review OR program divisions' proposed nuclear materials utilization schedules and amendments thereto and obtain appropriate approvals as necessary.

6. Evaluate preproduction inventories and all other stocks excess to current programmatic requirements to assure (1) approved use, (2) proper warehousing, (3) safeguarding, (4) timeliness of use, and (5) economy of use.

7. Conduct inventory analyses and other special analytical studies to assure proper utilization of nuclear materials and assist in the establishment of economic inventory levels, risks, and contingencies for base program plans and changes thereto.

I. Directors of Manufacturing, Research and Technical Support, and Uranium Enrichment Operations Divisions (contract administrators) sha11: 
1. Participate with the Materials Management Division in preparing plans, conducting analytical studies, and developing appropriate action in response to contractor appraisals .

2. Assure that contractors under their jurisdiction are knowledgeable of and implement the policies, procedures, and plans identified herein.

J. Each OR operating contractor shall recognize nuclear materials management policies and procedures identified herein in program planning and execution. Each OR contractor will appoint a staff representative for each operating site who will act as a Materials Management Coordinator. The Materials Management Coordinator should be aware of all site programs using nuclear materials and assure that the procurement, retention, usage, or return of nuclear materials by the contractor are optimized. 


\section{REPORTS}

The following routine reports are required:

a. Forecasts of Nuclear Material Requirements (see Appendix A).

b. Materials Management Plan (see Section IV.A.3.).

c. Assessment of June 30 Nuclear Material Inventories (see Appendix E).

d. Quarterly Allotment Status Report (see Appendix C).

e. Results of Contractor Materials Management Appraisal (see Appendix D).

\section{MATERIALS MANAGEMENT PROGRAM}

\section{A. General}

As in other management systems, materials management must include planning, implementation, and control functions.

The objective is to optimize the production, distribution, and utilization of nuclear materials resources. The management tasks which emerge as essential in this case include, inter alia, program planning, establishment of material allotments and inventory targets, identification of materials excess to program needs to facilitate redistribution, program assessments, and program/material cost trade-offs. Effective implementation of $O R$ assignments and responsibilities requires that these tasks be accomplished through the active participation of contractors, 
contract administrators, and the Materials Management Division.

\section{B. Planning}

1. General

a. Planning for optimum utilization of nuclear materials over an extended time period is the keystone to effective materials management. Factors to be considered in materials management planning include: (1) forecasts of nuclear material requirements; (2) full realization of the available nuclear materials inventories; (3) inventory management and the optimization of inventory levels; (4) identification of particular risks and development of contingency plans for meeting program objectives; and (5) identification of the interaction of materials management with other management functions (i.e., budget, safety, quality assurance).

b. Each contractor is required to establish the necessary policies and decision rules to assure that materials management activities are in accordance with the guidance and procedures contained herein.

c. The OR Materials Management Division will coordinate the development of OR-wide plans and studies related to nuclear materials utilization. 


\section{Forecasts}

a. Forecasts of nuclear material requirements are critical inputs to the decision models utilized in production and operations management, particularly those related to inventories, planning and scheduling, and production control.

b. Annual forecasts are prepared for each existing, authorized, and contemplated research, development, and reactor project (except those related to weapons production and nuclear materials production programs) having or needing nuclear materials during the ensuing 12 fiscal years. The forecasts are to be consistent with program and budget planning with stated inventory levels based upon the inventory management guidelines contained herein. The forecasts are to be submitted to OR for programmatic and materials management review in January of each year. OR will submit these forecasts with comments to appropriate HQ program divisions and the Division of Production and Materials Management (PMM).

c. HQ program division approved forecasts for nuclear materials are coordinated by PMM and issued to field 
offices in April-May of each year for use in the development of field office MMP's. The OR Materials Management Division will assemble the forecast data which serves as a base set of requirements for development of the OR MMP.

d. Forecasts are to be prepared on Form AEC-408 in accordance with instructions provided in Appendix $A$ and supplemental guidance as provided by PMM.

3. Materials Management Plans

a. OR must prepare an annual MMP which covers its projections of material balances and usage for a period of 12 years. This plan is submitted to PMM and appropriate HQ program divisions in May-June of each year. The plan is comprised of the following sections:

\section{(1) Material Usage Schedule}

This section is to provide an annual material balance by programs broken down by project numbers covering a period of 12 years. The plan is developed based upon AEC HQ approved forecasts and program assumptions and is to be consistent with the budget 
unless otherwise advised by the appropriate HQ program divisions and PMM through the OR Materials Management Division. The plan is to reflect optimum long-range utilization of nuclear materials. The material balances include a beginning inventory and projected annual withdrawals, returns, transfers in, transfers out, and usage (burnup, processing losses, decay, etc.) and the resulting projected annual ending target inventories.

The reporting units for all programs, unless otherwise authorized by PMM, are as follows:

Material Type Material to be Reported Reporting Units

\begin{tabular}{|c|c|c|}
\hline $\begin{array}{l}\text { Enriched uranium } \\
\text { Normal uranium } \\
\text { Plutonium }\end{array}$ & $\begin{array}{l}\text { U-235 isotope (show \% U-235) } \\
\text { Total U* } \\
\text { Total Pu (show \% Pu-240) }\end{array}$ & $\begin{array}{c}\text { Nearest whole } \\
\text { kilogram }\end{array}$ \\
\hline Heavy water $\left(D_{2} 0\right)$ & $\begin{array}{l}\text { U-233 isotope } \\
\text { D2 equivalent**}\end{array}$ & \\
\hline Depleted U & Total U*** & $\begin{array}{l}\text { Nearest whole } \\
1000 \text { kilogram }\end{array}$ \\
\hline $\begin{array}{l}\text { Pu-238 } \\
\text { Tritium }\end{array}$ & $\begin{array}{l}\text { Pu-238 isotope } \\
\text { Tritium }\end{array}$ & $\begin{array}{l}\text { Nearest whole } \\
\text { gram }\end{array}$ \\
\hline
\end{tabular}

* Normal uranium and $\mathrm{D}_{2} \mathrm{O}$ quantities of less than 100 kilograms on a project need not be reported.

**Conversion of $D_{2}$ to $D_{2} 0$ equivalent is accomplished by multiplying $\mathrm{D}_{2}$ gas weight by 5 . $\star \star \star$ Restricted to production programs only. 
(2) Risks/Contingency Plans for Meeting Target Inventories This section is to include significant risks which could seriously affect OR's ability to meet major inventory targets established in the MMP and related contingency plans for reducing or eliminating these risks. This section is intended to identify those activities in the budget, planning projections, etc., which are essential to the MMP.

(3) Options to Reduce Budget Expenditures through Materials Management Actions

This section is to include materials management actions that could be taken to reduce budget expenditures during the first three years of the plan. The trade-offs between material costs and budget savings are to be identified.

(4) Options and Risks Involved in Reducing Target Inventories

This section is to identify feasible actions that could be taken to reduce target inventory levels presented in the MMP. The risks associated with these actions with respect to meeting programmatic objectives, budgetary effect, health and safety, 
safeguards, etc., are to be identified for trade-off analyses.

b. The development of the OR MMP will be coordinated by the OR Materials Management Division with the assistance of contractors and contract administrators. The plan will be developed based upon decision criteria for optimum material utilization which are established and utilized by each contractor. The decision criteria should be periodically reviewed and revised as conditions warrant. Wherever possible, based on contractor decision criteria, computer models will be utilized in the development of long-range material usage schedules. The OR Materials Management Division will periodically review these models with each contractor to assure applicability to current and planned operating conditions.

c. Contractors should continually review their materials management activities and identify significant areas of risk and contingency plans to be considered, possible options for reducing budget expenditures, and means of reducing target inventories. Analytical studies performed in these reviews should conform to the general criteria contained in Appendix F. Significant findings 
should be submitted to the OR Materials Management Division through the contract administrators for review and possible inclusion in the OR MMP.

\section{Inventory Management}

\section{a. General}

Nuclear materials are a highly valuable resource which must be considered along with operating and capital costs in making decisions based on the total resources to accomplish program objectives at the lowest cost to the Government.

In more specific terms, the task of inventory management should be to equally evaluate costs and trade-offs of the various factors which affect total costs, including production operating costs, nuclear material inventory investment and holding costs, equipment/capital expenditures, etc., to determine the optimum level of resources required to meet production or development objectives.

The result of the application of this approach to 
inventory management is the identification of economic inventory levels I/ for approved production and development programs and clear identity of materials excess to current program needs. Fundamentals of inventory management, which are applicable to management of nuclear materials inventories, are presented in Appendix B.

b. Excepting material in the Uranium Enrichment Activity preproduction stockpile, nuclear material under the cognizance of $O R$ falls into one of three broad categories:

(1) Processing or fabrication operating inventory. This category is the one for which operating costs and production efficiency are most directly affected by the size of the inventory. When conducting a cost-benefit analysis on a process inventory, it must be shown that an increase in inventory over some minimum reference level will result in quantifiable reductions in operating costs which outweigh the charges associated with increased inventory levels.

1/Economic inventory level is the optimum quantity of nuclear material necessary to maintain a balance between in-process requirements and end-use demand. This level must be one that results in the lowest total cost of all resources, e.g., capital cost, operating costs, nuclear material, personnel, etc. 
(2) R\&D and special purpose materials. "Special Purpose" includes material held for uses not directly associated with either R\&D or production/production support such as materials held under surveillance programs. Inventory optimization for this category of material is primarity directed toward identifying materials which are in excess of known requirements such that these materials can be released for other uses. Cost-benefit studies should answer one of two questions:

(a) If the material is to be used in an approved program within the current budget year, is the amount of material on hand the minimum that will permit achievement of the program's objective?

(b) If the material is to be used for an approved program in the more distant future, will it be more economical to hold the material on hand or release it with replacement of similar material at a later date?

(3) Scrap. The management and optimization of scrap inventories are discussed in Section IV.B.5. of this handbook. 
If none of these considerations apply, the material should be categorized as excess material and reported to the OR Materials Management Division. This will assure that excess materials are specifically identified, enabling determination of the use of these materials which are in the best interest of the AEC. Excess materials should be reported in accordance with instructions provided in Appendix G.

c. The established market price of nuclear materials is to be utilized. If there is no market price or the market price is not firm or applicable in the specific situation, the OR Materials Management Division should be contacted to obtain an appropriate value.

\section{Scrap Management}

a. The basic principles of the scrap management program, as expressed by the General Manager on September 7, 1971, are:

(1) No AEC program or program division shall obtain or retain administrative or managerial control of materials in excess of the quantities required to 
support programs or projects approved in the program budgets, agency plans, and major changes in financial plans.

(2) All scrap and other materials not in active use or about to be taken out of active use shall be kept in, or promptly put into, safe and readily measurable geometries.

b. Aggressive reduction of scrap inventories serves to:

(1) Return valuable nuclear material to productive use,

(2) Reduce health, safety, and safeguards problems, and

(3) Storage costs.

c. The goal should be to reduce scrap backlogs essentially to the level of current generation and maintain this level.

d. Inventory control and recovery planning for scrap materials will be in accordance with AECM 7452 (in preparation) and applicable PMM guidance.

e. These guidelines should become an integral part of overall materials management planning.

C. Implementation

1. General

a. The annual MMP reflects the Commission-approved plan 
for utilizing nuclear materials inventories and for increasing the supply of those materials through the operation of production and reprocessing facilities, and by procurement or barter. The overall AEC MMP integrates the operating plans of the various $A E C$ organizations into a comprehensive program.

b. After Commission approval of the AEC MMP (approximately October 1), materials allotments based on approved program objectives are furnished to the AEC field offices by the AEC Materials Manager. Allotments will be provided by program division for two fiscal years (current and budget). These material allotments and established inventory targets are the key elements for managing nuclear materials throughout the AEC.

c. Appendix $C$ presents allotment and target inventory information pertinent to implementation of the AEC MMP.

2. Allotments

a. Issuance of Allotments. In fulfilling the field office assignments and responsibilities, the OR Materials Management Division shall issue allotments to each contract administrator for all programs and projects in 
the OR MMP following Commission approval of the AEC MMP. The materials usage schedules of the OR MMP shall serve as tentative allotments until Commission approval of the AEC MMP is obtained. Allotments will be expressed in terms of "withdrawals", "returns", "transfers in", and "transfers out" by type of material, project, and program division. The allotments, particularly "withdrawals" and "returns", should be considered as primary constraints.

b. Allotment Control

(1) Non-BB/DH Programs

All requests for nuclear material for non-BB/DH Program use should be made by use of Form AEC-437 Special Nuclear Material Draft. Each request shall be submitted to the appropriate OR contract administrator who, in turn, will process the request through the OR Materials Management Division to the appropriate supplying field office or OR supplying program division. When requests exceed authorized allotments, sufficient justification should be provided to expedite HQ program division \& PMM approval of the allotment increases. 
(2) BB Production User Programs and DH Program Because of their impact on Production Program operations and production supply, these wi thdrawal allotments should not be exceeded and returns should occur as planned unless approved changes have been obtained from appropriate HQ program divisions.

(3) BB Production Supply Programs

Though no specific controls are placed on material usage for BB Production supply programs, each OR contractor shall review materials usage at least quarterly and denote to the OR Materials Management Division significant factors which will alter the annual allotments.

\section{c. Reporting Allotment Status}

In order to provide for effective monitoring and control of allotments and identify appropriate adjustments to allotments and related materials management plans, each contractor is required to provide a quarterly allotment status report which indicates total "withdrawals", "returns", "transfers in", and "transfers out" for the 
current fiscal year through the quarter reported versus the total quantities allotted for the year. The report is to be submitted to the OR Materials Management Division through the $\mathrm{OR}$ contract administrators four weeks after the end of each quarter. An essential element of this report is explanatory comments which identify major variances expected during the entire year versus the quantities initially allotted. The report shall contain explanations of significant deviations in materials usage from annual allotments and information on changing conditions such as budget levels, program objectives, etc., which affect materials usage. The report for the fourth quarter of the FY should summarize and explain the differences between quantities allotted originally for the year versus the actual transactions.

\section{d. Allotment Changes}

Transactions which impact on production supply availability must be closely controlled. Therefore, should "withdrawals" and "returns" which have been issued to $O R$ contractors be expected to change significantly during a year from that allotted, requested allotment 
changes must be submitted to the OR Materials Management Division. Such requests should contain sufficient detail to enable a thorough evaluation of the change and $i$ ts impact on the AEC MMP. The level of changes in "withdrawals" and "returns" for which revised allotment approval is necessary is presented in Appendix C.

\section{Inventory Targets}

Materials management planning and analyses are based on projected material transactions and projected material inventory levels. The inventory levels represent quantities of material available in production supply for distribution to user programs and those expected to be utilized by user programs to meet their program objectives. For planning purposes, these projected inventory levels are considered to be inventory targets. Each contractor shall review inventory levels utilized in the OR MMP to assure that the targets are realistic and that such requirements can be met from existing or projected nuclear material availabilities. 
D. Control

1. General

To assure contractor performance to the materials management procedures and policies contained herein, the OR Materials Management Division will annually appraise contractor materials management performance through field surveys and formal reviews of OR contractor materials management activities. In addition, the OR Materials Management Division will annually assess contractor inventory levels to assure that inventory targets are realistic and represent economic inventory levels. Copies of the contractor appraisals and inventory assessments will be submitted to the AEC Materials Manager in accordance with field office assignments and responsibilities.

2. Contractor Materials Management Appraisal Activities Basic to the management of any program is the need to systematically review and evaluate the status or performance of the program. The objective of such appraisals is to provide management with feedback information as to the effectiveness of the program, the quality of performance, the adequacy and effectiveness of established policies and procedures, and actions necessary to improve the program. 
In planning and conducting materials management appraisals, it should be recognized that the success of these activities depends on the mutual cooperation and understanding of both the "appraisor" and the "appraisee" of the purpose, objectives, and scope of the appraisal. The AEC's materials management program utilizes the appraisal activity as the basic management control mechanism.

The OR Materials Management Division will appraise contractor materials management performance at least once every 12 months. Contractors subject to such appraisals are licenseexempt operating contractors and licensed contractors having AEC cost-type or fixed-price contracts and subcontracts with significant inventories of nuclear material (in the order of $\$ 1$ million or more). Objectives of the contractor materials management appraisal are to:

a. Assure that the contractor staff is aware of the objectives/goals of the AEC Materials Management Program.

b. Determine the adequacy of the contractor's materials management program.

c. Determine that the contractor is utilizing nuclear material inventories in an optimum manner and identifying materials in excess of approved program requirements. See Appendix $D$ for details on the scope of appraisals. 
3. Assessment of Contractor Inventories of Nuclear Materials Inventory assessments will be performed to ensure that materials are being effectively utilized in approved programs and that the inventory represents the economic inventory level required to meet program objectives. Development of a comprehensive $\mathrm{OR}$ inventory assessment report requires that each OR contractor submit to the OR Materials Management Division an annual assessment of the June 30 nuclear materials project inventories in accordance with the instructions provided in Appendix E. The assessment is to be submitted by September 1. The OR Materials Management Division will provide Composition of Ending Inventory report formats to each contractor for use in development of the inventory assessments. 
APPENDIX A

SPECIFIC PROCEDURES FOR PREPARING'NUCLEAR MATERIALS FORECASTS

\section{A. General}

Nuclear materials forecasts shall be submitted on Form AEC-408, "Forecast of Nuclear Material Requirements," (Exhibit 1) for specified nuclear materials. Nuclear materials to be reported and reporting units are as follows:

Material Type Mtl. to be Reported Reporting Units 3 /

$\left.\begin{array}{ll}\text { Enriched uranium } & \text { U-235 isotope } \\ \text { Normal uranium } & \text { Total } \mathrm{U} 1 / \\ \text { Plutonium } & \text { Total } \mathrm{Pu} \\ \text { U-233 } & \mathrm{U}-233 \text { isotope } \\ \text { Heavy water }\left(\mathrm{D}_{2} \mathrm{O}\right) & \mathrm{D}_{2} \mathrm{O} \text { I/ } \underline{2}\end{array}\right\} \quad$ Nearest whole kilogram

$\begin{array}{ll}\text { Pu-238 } & \text { Pu-238 isotope }) \quad \text { Nearest whole gram } \\ \text { Tritium } & \text { Tritium }\end{array}$

1/Quantities of less than 100 kilograms on a project need not be reported.

$2 /$ Conversion of $D_{2}$ to $D_{2} 0$ equivalent is accomplished by multiplying D2 gas weight by 5 .

3/Do not make entries for any amount of material rounding to less than one reporting unit.

From time to time, requirements may be established to forecast other materials. Specific instructions will be provided at that time. 


\section{B. Specific Instructions for Completion of Form AEC-408}

The specific instructions shown below correspond to the item numbers on Form AEC-408, "Forecast of Nuclear Materials Requirements."

1. (1-5). For projects on which Schedule 189a, "Program and Budget Proposal, Operating Costs and Equipment, Reactor Development Programs," are submitted to HQ, identify the fivecharacter number of the last Schedule 189a sent to HQ. (This requirement applies only to the Division of Reactor Research and Development projects.)

2. (6-15). Enter the 10-character alphanumeric project number. Contact the OR Materials Management Division for assistance, if needed, in developing project numbers for proposed projects. Material under PMM materials management control (projects prefixed with "M" and "E" designators) located at contractors, for which each field office has administrative responsibility, should be listed separately from non-"M" and non-"E" materials. Only entries 1 through 34 (Quarterly Forecasts) need to be filled out for "M" and "E" materials. Project numbers are defined in Section $C$ of this Appendix.

3. Project Title. Enter the title of the project number noted in Blocks (6-15). The project title should agree with the number contained in the official Project Number - Title Index. 
4. (16) Material Type. Insert the appropriate code applicable to all of the items on the page. List only one material type on Form AEC-408. Should one material require more spaces for entry types, continue on another Form AEC-408, repeating the material type, project number, title, etc.

\begin{tabular}{ll} 
Material Type & Code \\
\cline { 1 - 2 } U-235 & 1 \\
$\mathrm{Pu}$ & 2 \\
U-233 & 3 \\
Pu-238 & 4 \\
D20 & 5 \\
Normal U & 6 \\
Tritium & 7
\end{tabular}

5. (17) Entry Type Code. For every applicable assay of each material for each project, enter the entry type and entry type code for every line to show the status or transaction of the material. Below are the entry type codes and explanations of the transactions. Insert entry type under "Type", and enter code under Column 17 for each line. (Several lines may have the same entry type due to different assays.) Arrange entry types in numerical order and then from lowest to highest assay. 


\section{Code}

1

2

3

4

5

6

7

8

9

0

\section{Entry Type*}

Beginning Inventory

Withdrawals

Unirradiated Returns

Irradiated Returns

Transfers In

Transfers Out

Burnup and Losses

Formation

Launch

Ending Inventory

*Definitions of Entry Types. The following are the definitions of the entry types to be included in Block 17:

Beginning Inventory. The estimated inventory assigned to the project number as of the first day of the first fiscal year in the forecast period. A11 quantities assigned to the project should be included in this inventory irrespective of location. Withdrawals. The movement of material from Production Program (-BXXXX-projects) to non-Production Program (non-BXXXX-projects) when looked at from the side of the receiver. Material to be obtained by AEC contractors under AEC lease agreements are considered to be withdrawals.

Returns. A transaction looked at from the side of the shipper which reflects the movement of material from non-Production Program (non-BXXXX-projects) to Production Program (-BXXXXprojects). Includes processed scrap to be sent to Production Program by AEC contractors generating the scrap under AEC 
lease agreements.

Unirradiated Returns. Material which in its existing form has not been subjected to reactor irradiation.

Irradiated Returns. Material which in its existing form has been subjected to reactor irradiation.

Iransfers In. Material to be obtained for a project from another project but excludes material obtained as a result of "withdrawals." Includes materials to be obtained from other Federal Agencies, foreign countries, or private ownership. Material to be obtained from another location without a change in project number is not considered to be a transfer in. Material to be obtained by AEC from a licensee holding the material under an AEC lease agreement is a "transfer in" if. the material were not obtained by the licensee for AEC contract work; if the material were obtained by the licensee for the AEC contract work, the movement of material is not a transfer in. Transfers Out. Material to be removed from one project and provided to another project but excludes materials moved as a result of "returns." Includes materials to be provided to other Federal Agencies, foreign countries, or to domestic companies for private use. Material to be sent to another location or another contractor without a change in project number is not considered to be a "transfer out" but rather an intraproject transaction. 
Burnup and Losses. Consists of processing losses, fabrication losses, test losses, discards, burials, losses due to recovery, irradiation, and decay, whether occurring at AEC operating contractors or under lease agreements where the material is held for AEC contract work.

Formation. Material produced as a result of irradiation of other materials, e.g., U-233 or Pu produced in non-Production Program (non-BB) reactor.

Launch. Material removed from inventory as a result of rocket launch into space, e.g., Pu-238 SNAP units.

Ending Inventory. Inventory at the end of each fiscal year in total for project (irrespective of assay) calculated by adding receipts to the beginning inventory and subtracting all removals. For the first two fiscal years, enter the ending inventory in 4 th quarter data field.

6. (18-20) and (21-23). Enter assay for each entry type (see D.2.e.) except for the ending inventory (Code 0 ). With the exception of Entry Type Code 0 (Ending Inventory), assays sha11 be entered for each entry type, i.e., beginning inventory withdrawals, returns, etc., as follows: 


\section{Material Reported}

U-235

$\mathrm{Pu}$

U-233

$\mathrm{Pu}-238$

Normal U

$\mathrm{D}_{2} \mathrm{O}$

Tritium

\section{Assay Data}

Wt. $\%$ U-235 to nearest $0.1 \%$

Wt. $\% \mathrm{Pu}-240$ to nearest $0.1 \%$

Ppm U-232 in uranium*

Wt. $\% \mathrm{Pu}-238$ to nearest $0.1 \%$

Do not enter assay data

Do not enter assay data

Do not enter assay data

*Column 23 does not indicate tenths when assay is in ppm; therefore, last digit of ppm should appear in Column 23.

Single assays shall be shown in Blocks (21-23). Ranges of assays may be shown by using Blocks (18-20) for the lower assay and Blocks (21-23) for the upper assay. Ranges of assay should be avoided unless absolutely necessary. In particular, they should be avoided to describe beginning inventories (Entry Type Code 1). Use of assay ranges for withdrawals during the first two fiscal years will be interpreted as meaning that any material within the indicated assay range is acceptable. Weight percents should be shown for entries identified as burnup and losses (Entry Type Code 7). For material burned up in a reactor, enter the weight percent of the material loaded into the reactor prior to irradiation. Assays should be right 
adjusted, i.e., entries start at right and work left. A

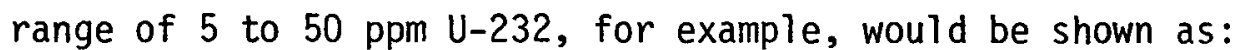

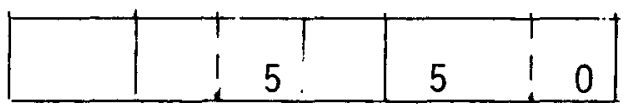

7. (24). For withdrawals, enter a code representing the form of material required from the Production Program as follows (normal standard form material only will be provided):

\begin{tabular}{cl} 
Code & \multicolumn{1}{c}{ Form } \\
1 & Hexafluoride \\
2 & Nitrate \\
3 & Metal \\
4 & Dioxide \\
5 & Other
\end{tabular}

8. (25-26). Special assay codes should be entered for irradiated $\mathrm{U}-235$ returns, $\mathrm{Pu}$ withdrawals and returns, and $\mathrm{D}_{2} \mathrm{O}$ withdrawals and returns, as follows:

Irradiated U-235

\begin{tabular}{lccc} 
Code & $\%$ U-236 & Code & $\frac{\% U-236}{1}$ \\
\cline { 2 - 4 } 01 & $<1$ & 09 & $8<9$ \\
02 & $1<2$ & 10 & $9<10$ \\
03 & $2<3$ & 11 & $10<11$ \\
04 & $3<4$ & 12 & $11<12$ \\
05 & $4<5$ & 13 & $12<13$ \\
06 & $5<6$ & 14 & $13<14$ \\
07 & $6<7$ & 15 & $15 \&$ above
\end{tabular}


Pu Withdrawals and Returns

\begin{tabular}{|c|c|c|c|c|c|c|c|c|c|}
\hline Code & \multicolumn{3}{|c|}{$\% \mathrm{Pu}-241$} & $\% \mathrm{Pu}-238$ & Code & \multicolumn{3}{|c|}{$\% \mathrm{Pu}-241$} & $\% \mathrm{Pu}-238$ \\
\hline 20 & & $<$ & 1 & $<.05$ & 28 & & $<$ & 1 & $.05-.10$ \\
\hline 21 & 1 & $<$ & 2 & $<.05$ & 29 & 1 & $<$ & 2 & $.05-.10$ \\
\hline 22 & 2 & $<$ & 3 & $<.05$ & 30 & 2 & $<$ & 3 & $.05-.10$ \\
\hline 23 & 3 & $<$ & 4 & $<.05$ & 31 & 3 & $<$ & 4 & $.05-.10$ \\
\hline 24 & 4 & $<$ & 5 & $<.05$ & 32 & 4 & $<$ & 5 & $.05-.10$ \\
\hline 25 & 5 & $<$ & 10 & $<.05$ & 33 & 5 & $<$ & 10 & $.05-.10$ \\
\hline 26 & 10 & $<$ & 15 & $<.05$ & 34 & 10 & $<$ & 15 & $.05-.10$ \\
\hline 27 & 15 & $\&$ & above & $<.05$ & 35 & 15 & $\&$ & above & $.05-.10$ \\
\hline
\end{tabular}

Pu Withdrawals and Returns

\begin{tabular}{|c|c|c|c|}
\hline Code & & $\mathrm{Pu}-241$ & $\% \mathrm{Pu}-238$ \\
\hline $\begin{array}{l}36 \\
37 \\
38 \\
39 \\
40 \\
41 \\
42\end{array}$ & $\begin{array}{r}1 \\
2 \\
3 \\
4 \\
5 \\
10\end{array}$ & $\begin{array}{lr}< & 1 \\
< & 2 \\
< & 3 \\
< & 4 \\
< & 5 \\
< & 10 \\
< & 15\end{array}$ & $\begin{array}{l}>.10 \\
>.10 \\
>.10 \\
>.10 \\
>.10 \\
>.10 \\
>.10\end{array}$ \\
\hline \multicolumn{4}{|c|}{$\mathrm{D}_{2} \mathrm{O}$ Withdrawals and Returns } \\
\hline Code & \multicolumn{3}{|c|}{$\mu \mathrm{Ci}$ Tritium/ml } \\
\hline $\begin{array}{l}50 \\
51 \\
52\end{array}$ & \multicolumn{3}{|c|}{$\begin{array}{l}<.00005 \\
.00005-30 \\
>30\end{array}$} \\
\hline
\end{tabular}

9. (27-29). For returns of irradiated and unirradiated U-235, normal uranium, $\mathrm{Pu}, \mathrm{U}-233$, and $\mathrm{Pu}-238$ enter the three-character classification code established by American National Standards Institute (ANSI) to designate major grade and subgrade.

(A1though the ANSI codes were established for unirradiated scrap, in this instance they should be applied to irradiated fuel also.) 
10. $(30-34) * *$ On the line reflecting beginning inventory (entry code 1), enter the estimated inventory for the project, regardless of location, as of the first day of the fiscal year to which the forecast applies. Include material being processed or fabricated for the project which is held under Lease Agreements. Judgment should be used so that materials of only slight differences in assay, say within one percent $\mathrm{U}-235, \mathrm{Pu}-240$, or $\mathrm{Pu}-238$, may be combined and reported as a single quantity with a single assay rather than a range.

11. (35-74) ** Enter appropriate quantities for each entry type (with the exception of beginning inventories which are entered in Blocks 30-34) for each quarter for the first two fiscal years and annually for the remaining 10 fiscal years. In the blank next to "FY" insert the 2-character number reflecting the appropriate fiscal year, e.g., 75, 76, 77, etc. 12 entries should be made to reflect consecutive fiscal years of the forecast period.

*Entries of quantities shall be right adjusted, i.e., entries shall start at right and work left. For example, $100 \mathrm{~kg}$ will be entered as follows:

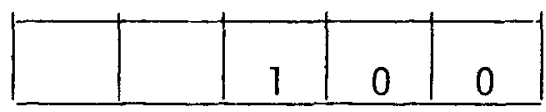


12. (75). Enter $\mathrm{P}$ or $\mathrm{F}$ to indicate the degree of probability of the forecast for withdrawals or returns only. $F$ is for firm - a forecast having a high degree of certainty that the withdrawals or returns will occur as stated; $\mathrm{P}$ is for probable, i.e., greater than $50 \%$ chance of occurring but less than firm. Possible entries, i.e., those having less than a $50 \%$ chance of occurring should not be included in the forecasts.

13. (76). For "transfers in" and "transfers out" only, enter "1" if the transfer is to occur within the allotment (e.g., transfers between two $\mathrm{OR}$ reactor research and development projects), or "2" if the transfer is to occur between two different allotments (e.g., transfers between an OR physical research project and an OR biomedical and environmental research project or between a Chicago physical research project and an OR physical research project).

14. (77-79). No entries are to be made in these blocks for quarterly forecasts.

Notes:

1. The origin of materials identified as "transfers in" and the destination of materials identified as "transfers out" should be noted at the bottom or the back of each applicable page. For materials identified as "transfers in", show the project number from which the material is to be obtained. For "transfers out", show the project number to which the material will be provided.

2. Inasmuch as Form AEC-408 is the data sheet used by the keypunch operator in preparing the ADP cards, special care should be taken in its preparation. All required entries should be completed either by typing or with a black heavy line pen which will result in clear copies when duplicated. 


\section{Project Numbers}

1. General

Project numbers are 10-character alphanumeric numbers which are used to identify nuclear materials for tasks or phases of work assigned to a field office by HQ program divisions. Project numbers generally are derived from the AEC Budget and Reporting Classification System (Appendix 1101, Part II). Consequently, they provide a link between nuclear material quantities and related financial data.

2. Coverage and Basic Requirements

a. Assignment of the first character of the project number is as follows:

A - Albuquerque Operations Office

B - Uranium Enrichment Activity

C - Chicago Operations Office

D - Savannah River Operations Office

E - Excess - Materials Management Program

F - Oak Ridge Operations Office

G - Grand Junction Office

H - Richland Operations Office

$\mathrm{J}$ - Idaho Operations Office

K - Schenectady Naval Reactors Office 
L - San Francisco Operations Office

M - Production and Materials Management Program (always should be followed by the letter $B$ in the second position)

N - Nevada Operations Office

P - Pittsburgh Naval Reactors Office

Q - Headquarters

b. Assignment of the second character (see Appendix 1101, Part II) of a project number is as follows:

A - Regulatory Activities

B - Nuclear Materials - Production Activities

H - Weapons Activities

J - Nuclear Material Security

K - Reactor Safety Research

L - Naval Reactor Development

N - Civilian Reactor Development

Q - Applied Technology (change pending)

R - Space Nuclear Systems

S - Applied Technology (change pending)

T - Physical Research

V - Controlled Thermonuclear Research 
$Y$ - Waste Management and Transportation (change pending, currently a "D")

2 - Special Activities (not related to a division, e.g., F-27777-77-77, "Sealed Source Module", F-29910-00-07, "Atomic Energy Mission Irradiation", etc.)

4 - Work for other Federal Agencies (not related to a division)

8 - Funded inventory (not related to a division)

c. An example of a nuclear material project number and a budget and reporting number:

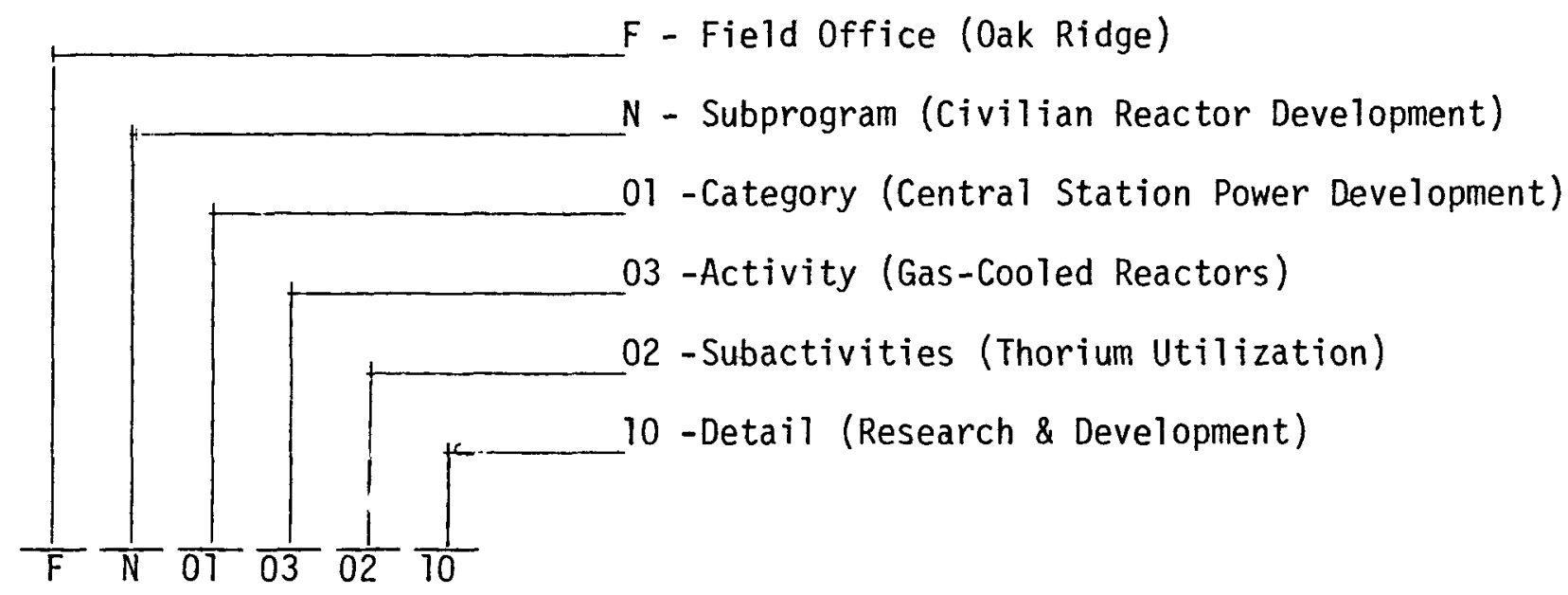

Note: Project F-N0103-02-10 related to B\&R HN-01-03-02-1. 
Exhibit 1

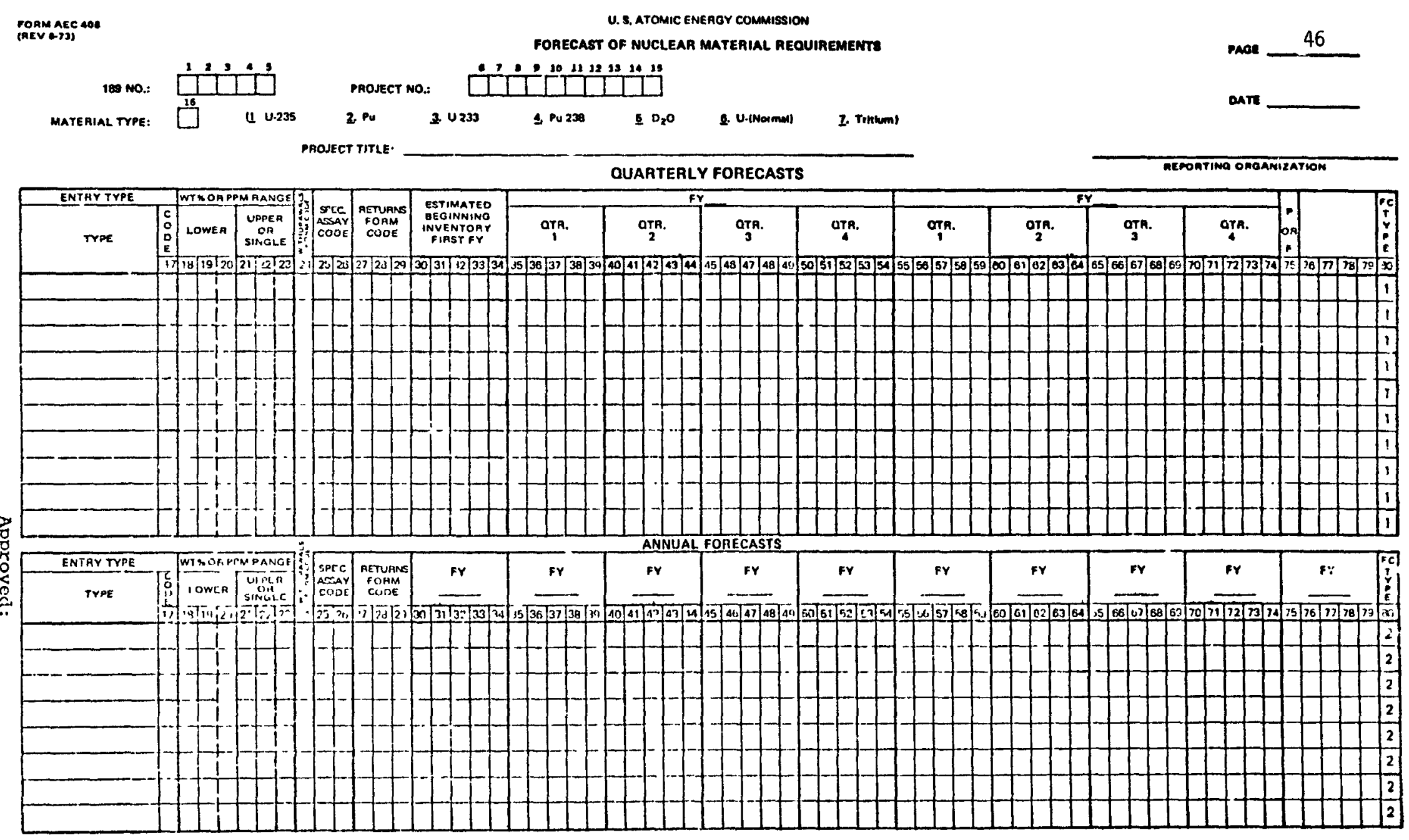




\section{APPENDIX B}

\section{FUNDAMENTALS OF INVENTORY MANAGEMENT}

\section{A. General}

The effective management of nuclear material inventories requires that these inventories be recognized by managers as a principal resource as are men, machines, and money. These nuclear material inventories are, in effect, idle resources for which costs can be associated: (1) a cost which increases as the inventory level increases; and (2) a cost which decreases as inventory increases. One cost which increases as the inventory does is the inventory carrying cost. This includes such components as handling and storage costs and inventory investment costs. The dollars expended in the establishment of existing nuclear materials inventories and the present and future market for these materials result in the need to consider the value of the material in inventory, the time period the material is in inventory, and the charge or interest rate placed on the inventory investment. For purposes of present inventory level analyses, the value of materials including value added through fabrication and a $10 \%$ annual imputed interest rate should be utilized. Interest rates which reflect the cost of money to the Government may be periodically revised. 
There are four principal costs which decrease as inventory increases:

1. Shortage or outage costs - Costs associated either with the inability to meet schedules or the delays in meeting schedules. As inventories increase, the likelihood of delays in meeting schedules decreases.

2. Setup and shutdown costs - Costs associated with preparing, processing, and closing out of manufacturing operations. Inventory increases permit larger production campaigns requiring less frequent production system setups, closeouts, and shutdowns.

3. Direct production costs - Increased inventories generally lead to more efficient utilization of manufacturing operations and lower unit costs of product.

4. Labor stabilization costs - Increased inventories decouple manufacturing operations and provide for minimizing the cost of hiring, firing, and training personnel as product demands change.

Effective inventory management requires an understanding of the relationship of inventory levels to production capability, manufacturing efficiency, and relevant costs such as those mentioned above. The inventory level at which relevant costs are minimized is defined as an economic inventory level. This is shown graphically as Exhibit 2. 
B. Analytic Approach to Inventory Management

1. General

In applying analytical techniques to inventory management, the following questions should be answered:

a. What are the functions of the inventory?

b. What is the relationship of inventory functions to the demand or usage characteristics of the product?

c. What is the relationship of inventory functions to production characteristics of the operation?

\section{Functions of Inventory}

a. Inventories are used to:

(1) Satisfy program requirements.

(2) Uncouple successive operations in the making of a product and promote operating efficiency.

(3) Reduce the risk of time loss in operations and in meeting program objectives.

b. These general functions are served in different ways by:

(1) Economic order lot and process inventory levels.

(2) Certainty of material availability and product utilization/shipments .

(3) Safety or fluctuation stocks. 
(a) Finished inventories that serve to protect program commitments and provide flexibility in responding to changing requirements.

(b) Process inventories that serve to shorten time to end-product demands or to absorb fluctuations in production rates.

(c) Raw material inventories that serve to protect against uncertainty in availability or delivery times and variations in usage rates.

(4) "Seasonal" stocks to absorb predictable variations between end-product demands and production rates.

\section{Demand Characteristics}

a. The size and frequency of orders. Larger orders characteristically require larger inventories than the same quantity withdrawn in more frequent but smaller orders.

b. Uniformity and predictability of demand. Handling large unpredictable fluctuations in demand requires flexibility and additional capacity in inventory production. Where fluctuations are predictable, advance planning techniques can be utilized.

c. Allowable delay in filling orders. Where allowable delays are small, inventory and production capacity must be correspondingly greater. 
d. The accuracy, frequency, and detail of demand forecasts. Fluctuation stocks exist basically because demand forecasts are not exact. The responsibility of forecast uncertainties for inventory needs should be clearly recognized.

\section{Production Characteristics}

a. Form of production organization. Job-shop versus production line organization. Inventory and production control is generally simpler under a product-line organization than in a job-shop.

b. Type of activity. Production, research and development, etc.

c. The number of manufacturing (or use) stages. Inventory management techniques could take advantage of differences in operating cost inventory levels or accomplishing production/R\&D tasks by alternative operating modes, schedules, etc.

d. The degree of specialization of the product at specific stages. Economies are often posșible in keeping the right balance of stock in the semi-finished state and by simplifying the control and scheduling of preliminary stages where the types of product are not diverse.

e. Required processing times at each stage. The length of delay between a replenishment order or change in production rate and effective action influences the size of inventory needed. 
f. Operations flexibility. Inventory management and production control are basically a question of striking a balance among production flexibility, production capacity, inventory levels, and material-use demands.

\section{Measure of Inventory Performance}

No single index serves to describe the performance of an inventory. Three interrelated factors must be considered:

a. The size of the inventory - dollar and unit amounts of the inventory averaged over a particular time period.

b. Inventory replenishment - costs and time required to replenish the inventory.

c. Service level - average stock availability in dollars or units; amount of stock which is available as a function of quantity demanded and lead time of demand notice.

\section{Inventory Level Indicators}

a. Consideration should be given to the development and use of inventory level indicators as they apply to the function under review. Examples of typical indicators which may be utilized are:

(1) Ratio of input to finished product (or shipments) per unit time for both: 
(a) Individual (unit) operations or stages; or

(b) Total material balance.

(2) An inventory volume versus input (throughput) index for each operation.

(3) Ratio of recycle and scrap generated to total input.

(4) Ratio of labor cost to material cost:

(a) Labor cost divided by value of material input; and

(b) Labor cost divided by cost of "having" material (use charge).

(5) Comparison of projected inventory levels with actual quantities.

(6) Economic order lot. The following is a general form of an equation which may be used to evaluate inventories utilizing the economic order lot concept:

$$
Q_{0}=\sqrt{\frac{2 C p R}{C_{H}}}
$$

Where:

$Q_{0}=$ Optimal lot size, in units.

$C p=$ Ordering cost in dollars.

$C_{H}=$ Inventory holding cost, dollars per unit per year.

$R=$ Annual requirements, in units per year. 
Exhibit 2

TOTAL PROGRAM COST OPTIMIZATION

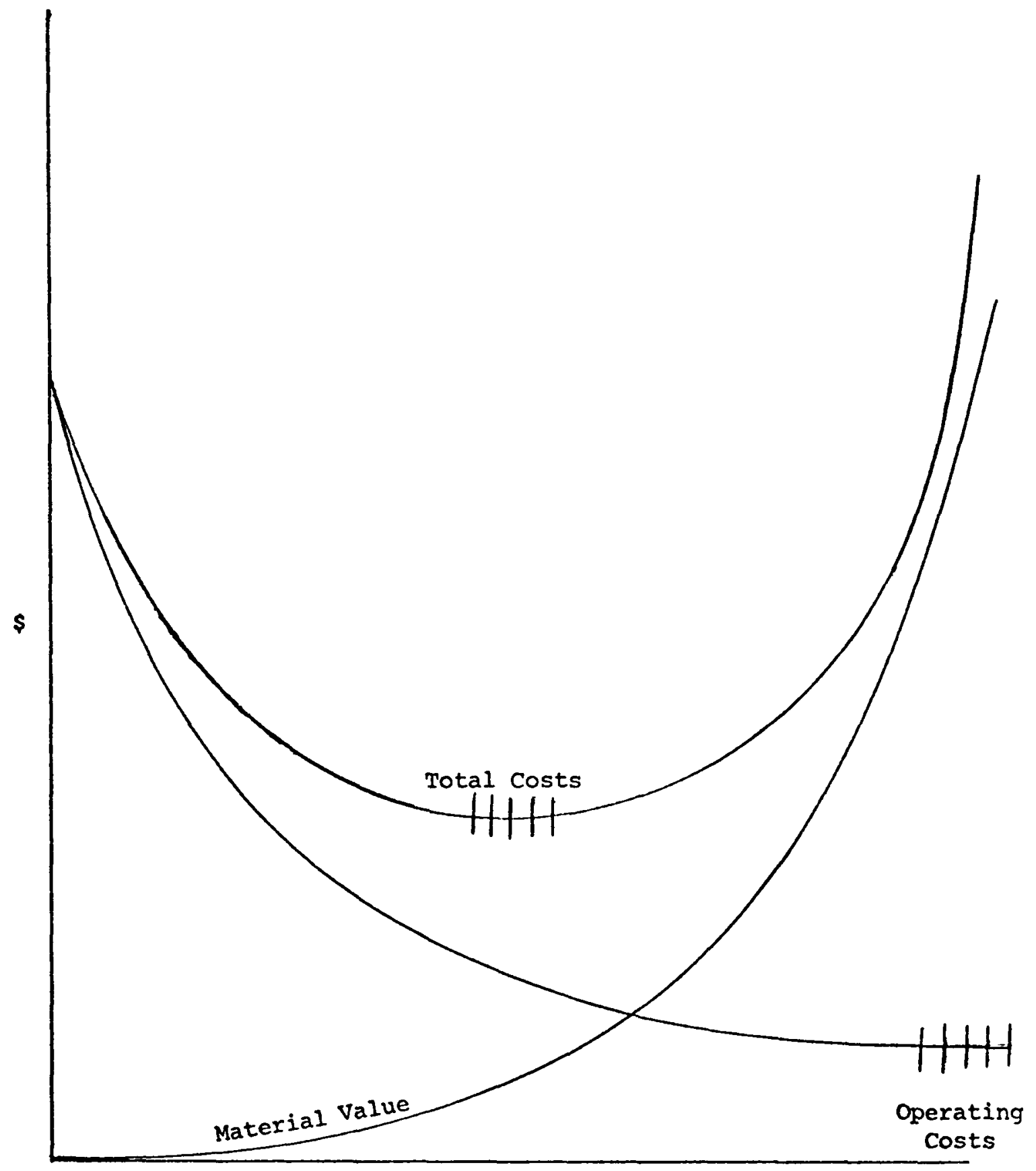

MATERIAL QUANTITIES 


\section{APPENDIX C}

\section{NUCLEAR MATERIAL ALLOTMENTS AND INVENTORY TARGETS}

\section{A. General}

The annual AEC-wide MMP reflects the Commission approved plan for utilizing nuclear material inventories and for increasing the supply of those materials through the operation of production and reprocessing facilities and by procurement or barter. The plan integrates the operating plans of the various $A E C$ organizations into a comprehensive program for materials management. One aspect of that program is related to the control of materials distribution. The key components of that control system are "allotments" and "inventory targets".

\section{B. Allotments}

\section{Terminology}

An allotment constitutes the scheduled movement of specific quantities of material by program division through a field office. The terms used to describe an allotment of materials for an organization are "withdrawals", "returns", "transfers in", and "transfers out". Proper categorization of material transactions into these terms depends on the flow of material and the viewpoint from which the movement is considered, i.e., the shipper or the receiver. In order to simplify use of the above terminology, 
it is desirable to consider that two major material flow systems exist. The first involves material transactions within the Production Program (BB Program) and the second involves material transactions between non-Production Programs (non-BB Programs) and the Production Program, other non-Production Programs, the Department of Defense (DOD), etc.

\section{a. Transactions Involving Non-Production Programs}

A materials transaction from the Production Program (BB) to a non-Production Program is called a "withdrawal" when viewed from the side of the receiver and a "transfer out" when viewed from the side of the shipper. Transaction of material from a non-Production Program to the Production Program is called a "return" when viewed from the side of the shipper and a "transfer in" when viewed from the side of the receiver. A transaction of materials between two non-Production Programs or between a non-Production Program and the DOD is considered to be a "transfer in" when viewed from the side of the receiver and a "transfer out" when viewed from the side of the shipper.

b. Intra-Production Program Transactions

Within the Production Program, materials are considered to be either part of Production supply or associated with 
"user" projects. If we assume that the main purpose of the production program is to produce materials, such as enriched uranium, plutonium, Pu-238, etc., for distribution to user programs, then the diversion of such materials from production supply to user programs is called a "withdrawal" when viewed from the side of the "user" and a "transfer out" when viewed from the side of the "supplier". For the reverse situation, the movement of materials from the user to production supply is called a "return" when viewed from the side of the shipper and a "transfer in" when viewed from the side of the receiver. Similarly, the transaction of materials between two user projects or two production supply projects within the Production Program are considered to be "transfers in" and "transfers out" as appropriate. Production Program projects which are considered to be user projects include process development projects, reactor projects (uranium fuel, plutonium for transplutonium production, heavy water for coolant/moderator, etc.).

c. Table of Transaction Categorization

The following table provides examples of material flows and their categorization as to withdrawals (W), returns (R), transfers in (TI), and transfers out (TO): 
Program to Program Transaction

Production to non-Production

Non-Production to Production

Non-Production to non-Production

Non-Production to DOD

DOD to non-Production

Intra-Prod. Program Transaction

Production Supply to Prod. User

Production User to Prod. Supply

Production User to Prod. User

Production Supply to Prod. Supply

Prod. Supply (Reactor Prod.)

\section{Category \\ Shipper Receiver}

TO

W

$\mathrm{R}$

TI

TO

TI

TO

$-\quad T I$

T0

W

R

TI

TO

TI

TO

TI

TI

\section{Issuance of Allotments}

Annually, after Commission approval of the AEC MMP (approximately October 1), PMM will issue materials allotments to $O R$ for the current fiscal year. The allotments will be expressed in terms of "withdrawals", "returns", "transfers in", and "transfers out" by type of material, program division, and field office. Tentative allotments may be issued before the Commission has acted on the AEC MMP as necessary to assure continuity of operations. These allotments will be based on the quantities of nuclear material appearing in the proposed AEC MMP. 


\section{Allotment Control}

Nuclear material allotments generally are considered to be operating constraints on the field offices. OR is responsible for establishing and implementing an appropriate system to monitor, control, and report the status of its allotments. In particular, it is important that user program withdrawals and returns allotments be monitored and controlled closely.

Because of their impact on Production Program operations and production supply, withdrawals allotments should not be exceeded and returns should occur as planned.

\section{Reporting Allotment Status}

$O R$ is required to provide PMM with a quarterly allotment status report which indicates total "withdrawals", "returns", "transfers in", and "transfers out" for the current fiscal year through the quarter reported versus the total quantities allotted for the year (original and all revisions). The report is due at HQ six weeks after the end of each quarter. An essential element of this report is the comments which explain major variances occurring or expected to occur during the entire year versus the quantities allotted. The report for the fourth quarter of the fiscal year should summarize and explain the differences 
between quantities allotted originally for the year versus the actual transactions.

\section{Allotment Changes}

"Withdrawals" and "returns" allotments are of particular importance because of their impact on the Production Program operations and related production supply availability. Due to extenuating circumstances, however, actual "withdrawals" and "returns" during a year may differ from the quantities originally allotted. Except for minor changes (noted below), OR must obtain PMM and HQ program division approval of changes in withdrawals and returns allotments. Requests for allotment changes should be sent to the Materials Management Division and contain sufficient details to enable a thorough evaluation of the proposed change. If the proposed change is acceptable to both the HQ program division and PMM, PMM will issue the revised allotment to $O R$, in writing, and provide a copy to the program division. Although changes in "transfers in" and "transfers out" may occur during the year, such changes will not require PMM approval. The reasons for such changes, 
however, should be explained in the quarterly allotment status reports. The level of changes in field office withdrawals and returns below for which revised allotment changes are unnecessary are:

\begin{tabular}{lcc} 
& \multicolumn{2}{c}{ Kilograms } \\
\cline { 2 - 2 } & $\begin{array}{l}\text { Weapons/Prod. } \\
\text { Programs }\end{array}$ & Other Programs \\
\cline { 2 - 2 } $\mathrm{Pu}$ & 100 & 10 \\
Enriched U & $250(U)$ & $25(\mathrm{U}-235)$ \\
Pu-238 & 0.5 & 0.5 \\
D20 & 1,000 & 100 \\
U-233 & 10 & 10 \\
Normal U & 10,000 & 1,000 \\
Tritium & 0.5 & 0.1 \\
ry Targets & &
\end{tabular}

1. Genera 1

Materials management planning and analyses are based on projected material transactions (covered under Allotments) and projected material inventory levels. The inventory levels represent quantities of material available in production supply for distribution to user programs and those expected to be utilized by user programs to meet their program objectives. For planning purposes, these projected inventory levels are considered to be 
the inventory targets and constitute the ending inventory required for the program. The typical materials management problem is to assure that inventory targets are realistic and that such requirements can be met from existing or projected availability.

2. Target Derivation

Inventory targets for $O R$ operating programs are predicated upon the materials usage schedules contained in the OR MMP. Inventory targets are established for the same time frame as the MMP, presently 12 fiscal years. Targets are analogous to fiscal year ending inventories and are calculated by taking the fiscal year beginning inventory, adding all receipts (withdrawals and transfers in), and subtracting removals (returns, transfers out, burnup, losses, decay, etc.)

3. Responsibilities

$O R$ contract administrators and contractors are required to realistically forecast their requirements so that inventory targets developed from such data are relevant to materials management planning. 
APPENDIX D

MATERIALS MANAGEMENT APPRAISAL ACTIVITIES

\section{A. Frequency and Scope of Appraisals}

The Materials Management Division will appraise OR contractor materials management activities at least once every 12 months. Appraisals will concentrate on the effectiveness of contractor programs and procedures for managing nuclear materials. Specific activities will include, but will not be limited to, the following:

1. Evaluation of inventory management. Determine if the material quantities in inventory and on order are reasonable with respect to minimum inventory levels required to meet program objectives.

2. Evaluation of contractor program and procedures to manage nuclear materials.

3. Evaluation of forecasts as to accuracy and completeness.

4. Determination that the contractor is using materials in the quantities and for the projects specifically authorized by the AEC.

5. Determination that the contractor reporting of nuclear material inventory data is accurate with respect to quantities, project identification, and composition of ending inventory. 
6. Determination that excess materials and scrap are being identified properly and reported promptly and that such materials are being disposed of at the earliest practicable date.

7. Evaluation of material allotments control system, where applicable.

8. Determination of the adequacy of information provided by contractors responsible for developing materials management plans. In particular, determine if the contractor has presented realistic risks, options, and contingency plans.

9. Determination that contracts and subcontracts issued by the contractor contain adequate materials management provisions to assure optimization of materials utilization.

10. Determination if the contractor is responsive to routine and special field office requests for materials management information, such as reports of assessment of inventories.

11. Evaluation of analytic studies performed by the contractor related to materials optimization.

\section{B. Reports}

A formal report appraising contractor materials management will be issued within eight weeks after the appraisal visit to the contractor's site. The reports of contractor appraisals generally shall be 
provided to the contractor, PMM, and the applicable HQ program divisions. Reports of findings directed to licensed contractors and subcontractors (having material under fixedurice or cost-type contracts) will be primarily directed to violations of materials management provisions of the contract. A copy of the apprcved report will be sent to PMM and the appropriate HQ program division. 


\section{APPENDIX E \\ ASSESSMENT OF CONTRACTOR INVENTORIES OF NUCLEAR MATERIALS}

The following instructions are provided for preparation of the annual nuclear materials inventory assessment report:

A. Inventory Date. Nuclear materials on inventory as of June 30 shall be assessed.

B. Reporting Responsibility. The assessment should cover nuclear materials for which $O R$ has programmatic responsibility or in the case of nuclear materials production or weapons production operations, contract administration responsibility. This responsibility is identified by the prefix in the alphanumeric project number which identifies all AEC program nuclear materials.

C. Materials to be Reported. The assessment should cover the following material inventories:

1. Enriched Uranium (EU).

2. Normal Uranium (NU).

3. Plutonium $(\mathrm{Pu})$.

4. Plutonium-238.

5. Uranium-233.

6. Tritium.

7. Heavy Water $\left(\mathrm{D}_{2} \mathrm{O}\right)$ and deuterium gas.

8. Depleted U (Production Program only). 
D. Analysis Required. Assessments should be prepared on a project inventory level basis with supporting details, as necessary, provided by applicable line item in appropriate Composition of Ending Inventory (COEI) reports or as otherwise agreed to by the OR Materials Management Division. The level of detail provided should be determined by the significance of the inventory and the particular program inventory being assessed. If COEI report formats are used, explanations may be omitted for any line item having less than $1 \mathrm{~kg} \mathrm{U}-235$ (EU), Pu or U-233, $100 \mathrm{~kg} \mathrm{NU}$, depleted U or equivalent $D_{2} 0$ ( $D_{2} \times 5=D_{2} \mathrm{O}$ equivalent), $100 \mathrm{gm} \mathrm{Pu}-238$, and $10 \mathrm{gm}$ tritium.

E. Source of Data. Contractors using COEI report formats in reporting their inventory assessments will be provided with appropriate Nuclear Materials Information System (NMIS) reports.

F. AEC Contract Material Held by Commercial Vendors. AEC contract material held by commercial vendors under Lease Agreement is not included in COEI reports prepared under NMIS. SUch material, however, must be included in the $O R$ assessment reports, as appropriate. It will be the responsibility of the contract administrator having nuclear materials under such contracting arrangements to determine the quantity of material and to provide adequate assessment details. 
G. Assessments. Complete and thorough assessments should be provided of inventories so that the reader can have a good understanding of how and why materials are being utilized or not utilized. The explanations should contain sufficient information to facilitate the evaluation of inventory levels relative to programmatic objectives and a determination as to whether the inventory represents an economic inventory level. The mere re-statement of composition of ending inventory categories is not adequate. The key to the assessment of inventories, associated with processing operations, fabrication operations, reactor operations, scrap processing operations, etc., is the rate of inventory utilization, throughput, or turnover. The circumstances related to all inactive or apparently inactive materials should be clearly identified. The time sequence of utilization should be specified when preprocessing or prefabrication inventories exist. Information such as problems in disposing of scrap, irradiated fuel, or other excess materials, and the time frame in which actual disposal is anticipated should be specified. In effect, the assessment is not merely a look at the inventory at a point in time but must include plans in terms of quantities and time frame to make the review dynamic in nature. Significant recent materials management activities, reduction of inventories, identification of excess materials, etc., also should be reported. 


\section{APPENDIX F}

ANALYTICAL STUDIES

\section{A. Genera]}

Analytical studies whether they be complex computer models or paper studies, are necessary in managing resources if optimum solutions to problems are to be formulated. In managing the AEC's nuclear material resources, analytical studies should play a key role in the decision-making process in evaluating materials/ budgetary trade-off options, recovery of scrap/irradiated materials, comparing alternative materials management plans, etc.

The major steps involved in the development and use of an analytical study will normally be as follows:

1. Define the Problem. This covers the area of isolating the scope of the study and identifying the major varaibles involved.

2. Collect Data. Once the major study variables have been defined, the relevant data (cost estimates, production rates, value of material, etc.) need to be collected or generated.

3. Use of Analytical Methods. The analytical technique/concepts suitable for evaluating the data must be determined. Studies conducted may utilize one or more of the following concepts:

a. Increment Analysis. Measures the impact of decision al ternatives on costs (budgets) stressing the changes in 
total costs (budgets) that result from changes in operating plans, material recovery schedules, procedures, etc.

Incremental cost, which may be defined as the change in total cost resulting from a decision to change a base plan or operating mode, is a common example of the increment analys is concept. Generally, a decision is sound if it increases value received more than the costs involved, or reduces costs more than the value loss as a result of the decision.

b. Time Perspective. Decisions should take into consideration the short- and long-term effects on costs and values involved, giving the appropriate weight to the most relevant time periods.

c. Discount Analysis. If a decision affects costs and values over an extended time frame, it is necessary to discount the costs/values to present values before a valid comparison of alternatives is possible. This concept reflects the time-value of money principle in that a dollar received tomorrow is worth less than a dollar expended today. The discount rate used equates cash flows that occur over a time span to the decision date. The discount rate used 
should reflect the anticipated cost of money to the Government over the study period. An annual discount rate of $10 \%$ is to be utilized unless otherwise notified.

\section{B. Types of Analytical Studies}

The following list provides examples of the type of analytical studies involved in managing the AEC's existing and planned nuclear material resources:

1. Value of SNM.

2. Alternative methods for producing/supplying SNM.

3. Scrap recovery/disposal analysis.

4. Economics of reprocessing irradiated fuel.

5. Order quantities for reactor fuel procurement or fabrication.

6. Use of alternative SNM for program mission requirements.

7. Determination of optimum inventory levels.

8. Costs/benefits of reducing inventory levels.

9. Utilization of excess material to meet program requirements.

10. Operational material requirement trade-offs.

C. Definitions

In performing analytical studies related to materials management, the following definitions apply:

1. Total costs - materials, operating, and plant/equipment costs. 
2. Incremental cost - the change in total costs resulting from a change to an approved or current plan of operation.

3. Marginal cost - the change in total cost resulting from a unit change in output.

4. Sunk cost - costs arising from actions taken in the past and unaffected by any subsequent decision.

5. Discount rate - the interest rate used in calculating the present value of expected yearly cash flows (costs/benefits). 


\section{APPENDIX G}

\section{EXCESS MATERIALS}

\section{A. General}

Excess materials management is concerned with the identification, characterization, and mechanisms necessary to effect timely disposition of the excess nuclear material. The availability of safe storage, the existence of recovery capability, the potential usefulness of the material in its existing form to approved AEC programs or those of other Government agencies, and its value to industry, all have a bearing on its disposition. Dollars may be saved due to reduced production requirements and, in those cases where material can be reutilized, it can save fabrication and processing dollars as well as time in implementing or accelerating ongoing programs.

\section{B. Definitions}

1. Excess Nuclear Material is nuclear material for which there is no planned or approved programmatic use during the near-term.

2. Usable Excess Material is nuclear material which is suitable for reuse in its existing form. It consists of material in standard and/or specially prepared form. 
3. Unusable Excess Material is nuclear material which is not suitable for any programmatic use in its existing form. This is a general term to include materials such as spent fual and scrap.

4. Spent Fuel is irradiated nuclear material which contains fission products, requires shielded storage and handling facilities, and is in an unusable form.

5. Scrap Material is unirradiated nuclear material that is not usable in its existing form, is mixed with other material necessitating purification to be rendered useful, and which can be recovered in an economical and safe manner.

6. "M" Material is usable excess nuclear material in a form suitable for direct introduction into SNM production processes and has been assigned an "M" prefix to the project number in the Nuclear Materials Information System (NMIS).

7. "E" Material is unusable excess nuclear material for which PMM has management responsibility and to which it has assigned an "E" prefix to the project number. It consists of scrap material declared to the Central Scrap Management Office (CSMO) and spent fuel not recoverable in the near term. The program division holding "E" material continues to be responsible for safe storage and all handling, packaging, and shipping charges associated with its eventual disposition. 


\section{Excess Materials Reporting}

\section{General}

To obtain proper identification and assure effective utilization of excess materials, each contractor is to identify and report to $O R$ all nuclear materials which become excess to current programmatic needs. A11 excess scrap materials which are not intended for programmatic use as recycle materials are to be reported to the appropriate $O R$ program division and, subsequentiy, to the appropriate Central Scrap Management Office (CSMO) for disposition. All other excess materials are to be reported to the OR Materials Management Division.

2. Unusable Excess Materials

a. Scrap materials will be disposed of consistent with AEC policy and procedures as provided for by AECM 7452 (in preparation) and applicable PMM guidance. Contractors are to submit scrap declarations to the appropriate OR program division for review and forwarding to the appropriate CSMO and are required to report semiannually to the OR Materials Management Division the status of scrap materials under their management control.

b. Spent fuel for which present or near-term recovery capability is unavailable should be reported to the OR Materials Management Division on a current bas is such that 
requests for "E" project number assignments can be forwarded to PMM. The report should include the project number, location, type, and quantity of contained SS materials, and a physical and chemical description of the spent fuel.

\section{Usable Excess Materials}

a. Excess production program materials such as ore concentrates, cascade tails, metal, oxides, and other compounds which become excess should be reported to the OR Materials Management Division such that requests for " $M$ " project number assignments can be forwarded to PMM. These materials will continue to be held by the OR Materials Management Division. These materials can be made available for program use subject to OR and PMM approval.

b. Research and development materials should be reported to the OR Materials Management Division at the time they are identified as excess to program requirements so their disposition can be effected in a timely manner.

4. Data Elements to be Reported

a. Al1 reports, requests, and correspondence on excess nuclear material should include the project number, location, material type code, COEI line number, physical and chemical form, and quantities of both element and isotope. 